\title{
Intermediate-Scale lon Exchange Removal of Technetium from Savannah River Site Tank 44 F Supernate Solution
}

by

W. D. King

Westinghouse Savannah River Company

Savannah River Site

Aiken, South Carolina 29808

D. J. McCabe

N. M. Hassan

D. D. Walker

This paper was prepared in connection with work done under the above contract number with the U.S. Department of Energy. By acceptance of this paper, the publisher and/or recipient acknowledges the U. S. Government's right to retain a nonexclusive, royalty-free license in and to any copyright covering this paper, along with the right to reproduce and to authorize others to reproduce all or part of the copyrighted paper. 


\section{DISCLAIMER}

This report was prepared as an account of work sponsored by an agency of the United States Government. Neither the United States Government nor any agency thereof, nor any of their employees, makes any warranty, express or implied, or assumes any legal liability or responsibility for the accuracy, completeness, or usefulness of any information, apparatus, product or process disclosed, or represents that its use would not infringe privately owned rights. Reference herein to any specific commercial product, process or service by trade name, trademark, manufacturer, or otherwise does not necessarily constitute or imply its endorsement, recommendation, or favoring by the United States Government or any agency thereof. The views and opinions of authors expressed herein do not necessarily state or reflect those of the United States Government or any agency thereof.

This report has been reproduced directly from the best available copy.

Available for sale to the public, in paper, from: U.S. Department of Commerce, National Technical Information Service, 5285 Port Royal Road, Springfield, VA 22161, phone: (800) 553-6847

fax: (703) 605-6900

email: orders@ntis.fedworld.gov

online ordering: http://www.ntis.gov/ordering.htm

Available electronically at http://www.doe.gov/bridge

Available for a processing fee to U.S. Department of Energy and its contractors, in paper, from: U.S. Department of Energy, Office of Scientific and Technical Information, P.O. Box 62, Oak Ridge, TN 37831-0062, phone: (865) 576-8401

fax: (865) 576-5728

email: reports@adonis.osti.gov 


\section{DISCLAIMER}

Portions of this document may be illegible in electronic image products. Images are produced from the best available original document. 


\title{
(ख) Obnfl (ia)
}

\section{Intermediate-Scale Ion Exchange Removal of Technetium from Savannah River Site Tank 44 F Supernate Solution}

\author{
July 3,2000
}
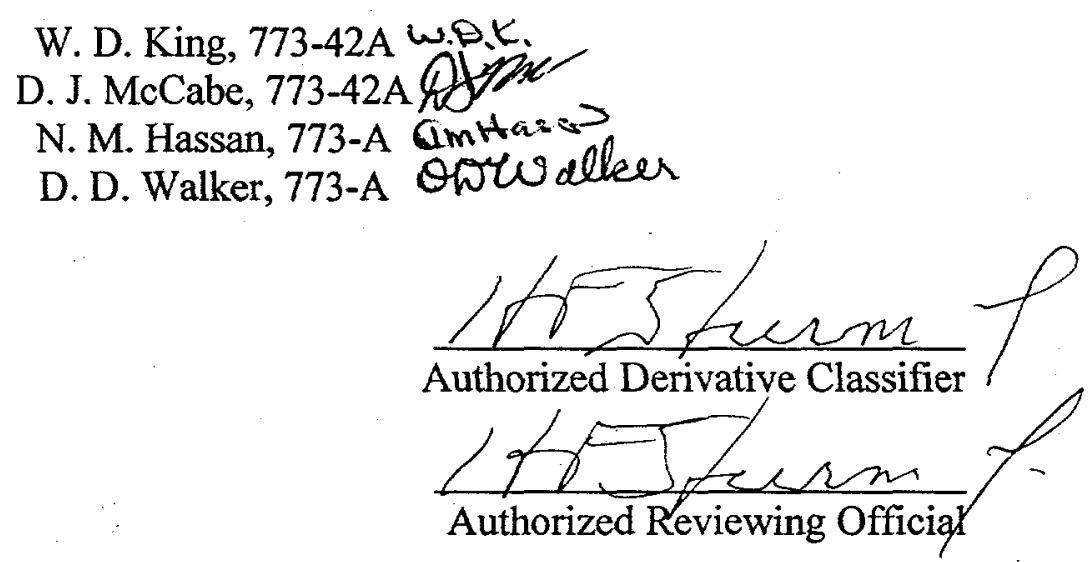

\section{DISCLAIMER NOTICE}

This report was prepared by Westinghouse Savannah River Company, Inc. (WSRC) on behalf of the U.S. Department of Energy (DOE), as an account of work sponsored by BNFL, Inc. Neither WSRC, DOE, the U.S. Government, or any person acting on their behalf makes any warranty, express or implied, or assumes any legal liability or responsibility for the accuracy, completeness, or usefulness of any information, apparatus, product, or process disclosed, or represents that its use would not infringe privately owned rights. Reference herein to any specific commercial product, process, or service by trade name, trademark, manufacturer, or otherwise, does not necessarily constitute or imply its endorsement, recommendation, or favoring by WSRC, DOE, or the U.S. Government. The views and opinions of authors expressed herein do not necessarily state or reflect those of WSRC, DOE, or the U.S. Government.

Savannah River Technology Center

Westinghouse Savannah River Company

Aiken, SC 29808 
Table of Contents

List of Tables iii

List of Figures iv

SUMMARY V

1.0 INTRODUCTION $\quad 2$

2.0 EXPERIMENTAL 3

2.1. Materials . 3

2.2 Equipment and Procedures 4

2.2.1 Batch Contact Experiment 4

2.2.2 Column Experiment $\quad 5$

3.0 RESULTS AND DISCUSSION 9

3.1 Batch Contact Experiment 9

3.2 Column Experiment $\quad 9$

$\begin{array}{lll}4.0 & \text { CONCLUSIONS } & 13\end{array}$

$\begin{array}{ll}\text { 5.0 DESIGN CHECK } & 15\end{array}$

$\begin{array}{lll}6.0 & \text { APPROVALS } & 15\end{array}$

$\begin{array}{ll}\text { 7.0 REFERENCES } & 15\end{array}$

$\begin{array}{lll}\text { 8.0 APPENDIX } & 17\end{array}$

8.1 Attachment 1. SuperLig ${ }^{\circledR} 639$ Batch Contact Data 17

8.2 Attachment 2. SuperLig ${ }^{(39}$ Column Data 18

8.3 Attachment 3. Characterization of the Composited Tc Eluate 19

8.4 Attachment 4. SuperLig ${ }^{\circledR}$ 639 Resin Analysis Data 21 


\section{List of Tables}

Table 1. Physical Characteristics of "As-Received" SuperLig ${ }^{\circledR} 639$ Resins 3

Table 2. Sr/Cs-Decontaminated SRS Tank 44 F Waste Composition $\quad 4$

Table 3. Characterization of SuperLig ${ }^{\bowtie} 639$ Column Post-Feed $\mathrm{NaOH}$ Wash Solutions 


\section{List of Figures}

$\begin{array}{lll}\text { Figure 1. Ion Exchange Column Design } & 6\end{array}$

Figure 2. SRS Tank 44 F Technetium Ion Exchange Column Apparatus $\quad 7$

Figure 3. SuperLig $^{\circledR} 639$ Column Technetium Breakthrough Profile with SRS Tank 44 F Solution

Figure 4. SuperLig ${ }^{\circledR} 639$ Column Technetium Elution Profile with SRS Tank 44 F Solution

Figure 5. SuperLig ${ }^{\circledR} 639$ Column Technetium Elution Profile with SRS Tank 44 F Solution - Semi-Log Plot 


\section{SUMMARY}

As part of the Hanford River Protection Project waste treatment facility design contracted to BNFL, Inc., a sample of Savannah River Site (SRS) Tank $44 \mathrm{~F}$ waste solution was treated for the removal of technetium (as pertechnetate ion). Interest in treating the SRS sample for Tc removal resulted from the similarity between the Tank $44 \mathrm{~F}$ supernate composition and Hanford Envelope A supernate solutions. The Tank $44 \mathrm{~F}$ sample was available as a by-product of tests already conducted at the Savannah River Technology. Center (SRTC) as part of the Alternative Salt Disposition Program for treatment of SRS wastes. Testing of the SRS sample resulted in considerable cost-savings since it was not necessary to ship a sample of Hanford supernate to SRS. The baseline Tc removal technology selected by BNFL is SuperLig 639 ion exchange resin (a proprietary, elutable, organic material). Besides providing important design information for the waste treatment facility to be constructed at Hanford, this test is the first ion exchange column experiment conducted on SRS waste with SuperLig ${ }^{\circledR} 639$ resin. The Tank 44 F sample had been previously treated with monosodiumtitanate to remove radioactive strontium, filtered, and passed through a column of crystalline silicotitanate (Ionsiv ${ }^{\circledR}$ IE-911) to remove radioactive cesium as part of the Alternative Salt Disposition Program. Batch contact and column tests were performed on the $\mathrm{Sr} / \mathrm{Cs}$-decontaminated Tank $44 \mathrm{~F}$ supernate with SuperLig ${ }^{\circledR} 639$ ion exchange resin to remove technetium. A single 24 hour batch contact with the Tank $44 \mathrm{~F}$ sample resulted in approximately $89.4 \% \mathrm{Tc}$ removal ( $\mathrm{Tc} \mathrm{Kd}=950.1 \mathrm{~mL} / \mathrm{g}$ ), indicating that SuperLig ${ }^{\otimes} 639$ resin has a high capacity for $\mathrm{Tc}$ and that the predominate form of Tc in Tank $44 \mathrm{~F}$ waste is pertechnetate $\left(\mathrm{TcO}_{4}^{-}\right)$. Only $45 \%$ Tc breakthrough was observed after 579 CV (29.3 L) of Tank 44 supernate had been processed through a $50.6 \mathrm{~mL}$ column of SuperLig 639 resin (resin: 50:50 mixture of batches 981015DHC720011 and 990420DHC720067, column ID: $2.7 \mathrm{~cm}$, feed flow rate: $3.1 \mathrm{CV} / \mathrm{hr}$ ). The column test was highly successful in demonstrating Tc removal from SRS Tank $44 \mathrm{~F}$ supernate. The excellent performance is related to the low concentration of nitrate ion in this sample, which is known to compete with pertechnetate on the resin. The Tc was subsequently eluted from the column with water. The bulk of the Tc was eluted from the column within $12 \mathrm{CV}$ after the start of the elution cycle. However, the [Tc] in the eluate did not decrease to within $1 \%$ of the feed [Tc] (the current plant design target) until $\sim 50 \mathrm{CV}$ of eluent had been processed. Further work is needed to develop methods to decrease the eluent volume and the elution duration required for SuperLig 639 columns. 


\subsection{INTRODUCTION}

The pretreatment process for the Hanford River Protection Project contracted to BNFL, Inc. is to provide decontaminated low activity waste and concentrated eluate streams for vitrification into low and high activity waste glass, respectively. The pretreatment includes precipitation and filtration to remove strontium, transuranics, and entrained solids, and ion exchange processes to remove cesium and technetium. The current plant design utilizes SuperLig ${ }^{\text {ion }}$ exchange resins to remove cesium and technetium (the primary radioactive constituents) from the Hanford low activity waste (LAW). This report describes ion exchange testing to remove technetium from a Savannah River Site Tank $44 \mathrm{~F}$ waste solution as part of the BNFL Program. Interest in treating the SRS sample for Tc removal resulted from the similarity between the Tank $44 \mathrm{~F}$ supernate composition and Hanford Envelope $A$ waste solutions, and the ready availability of the sample as a by-product of Alternative Salt Disposition Program testing at the SRTC.

The conceptualized process for pretreatment of Hanford LAW utilizes. SuperLig ${ }^{\circledR} 639$ ion exchange resin (a proprietary material) for the removal of Tc-99 (pertechnetate form only). SuperLig ${ }^{\circledR} 639$ is an elutable, organic resin prepared by attaching a highlyselective ion exchange material to preformed polystyrene beads. The resin removes a salt pair (e.g. $\mathrm{NaTcO}_{4}$ and $\mathrm{NaNO}_{3}$ ) from acidic or basic solutions. Nitrate anion concentration is inversely related to the adsorption of pertechnetate from the contacting solution. Other anions at concentrations typically present in radioactive waste solutions at Hanford and SRS (e.g. $\mathrm{OH}^{-}, \mathrm{Cl}^{-}, \mathrm{F}^{-}, \mathrm{CO}_{3}^{2-}, \mathrm{NO}_{2}^{-}, \mathrm{SO}_{4}{ }^{2-}$ ) do not significantly affect the adsorption of pertechnetate by SuperLig ${ }^{8} 639$ resin. Lowering the ionic strength of the solution in contact with the resin reverses the technetium adsorption process. In this way, sodium pertechnetate can be eluted from SuperLig ${ }^{\circledR} 639$ resin using water or dilute nitric acid solution. SuperLig 639 resin has not been used previously for technetium removal with SRS supernate. The Tank $44 \mathrm{~F}$ sample is a "high hydroxide" supernate, containing a considerably lower nitrate concentration and higher hydroxide concentration $(0.5 \mathrm{M}$ $\mathrm{NO}_{3}^{-}, 4.5 \mathrm{M} \mathrm{OH}, 5.4 \mathrm{M} \mathrm{Na}^{+}$) than previous radioactive samples tested with this resin.

Batch contact tests and intermediate-scale column tests $(50.6 \mathrm{~mL}$ resin bed, $2.7 \mathrm{~cm}$ column ID) were performed on the Tank $44 \mathrm{~F}$ solution with SuperLig 639 resin in the Shielded Cells Facility at SRTC. This data will be used as input to a computer model to determine scale-up parameters for actual plant operation. The computer modeling work will be reported in a future document. 


\subsection{EXPERIMENTAL}

\section{$\underline{2.1 \text { Materials }}$}

Three batches of SuperLig 639 resin were received from IBC Advanced Technologies, American Fork, Utah. All resin samples were composed of tan, spherical beads and were very similar in appearance. Some physical data reported in an earlier document for the SuperLig 639 resins is provided in Table 1. ${ }^{1}$ A batch contact test was performed with Tank $44 \mathrm{~F}$ solution (previously treated to separate cesium and strontium) using batch \#981015DHC720011. The Tank 44 F column experiment was conducted using a 50:50 mixture (by as-received weight) of batches 981015DHC720011 and 990420DHC720067.

Table 1. Physical Characteristics of "As-Received" SuperLig 639 Resins

\begin{tabular}{|c|c|c|c|}
\hline Batch \# & $\begin{array}{c}\text { Resin particle } \\
\text { density }(\mathrm{g} / \mathrm{mL})\end{array}$ & $\begin{array}{c}\text { Bulk dry density } \\
(\mathrm{g} / \mathrm{mL})\end{array}$ & $\begin{array}{c}\text { Water content } \\
(\%)\end{array}$ \\
\hline $980624001 \mathrm{DC}$ & 1.219 & 0.489 & 1.4 \\
\hline $981015 \mathrm{DHC720011}$ & 1.147 & 0.468 & 1.3 \\
\hline $990420 \mathrm{DHC} 720067$ & not measured & 0.479 & not measured \\
\hline
\end{tabular}

The Sr/Cs-decontaminated and filtered Tank $44 \mathrm{~F}$ sample composition is given in Table 2. The primary waste composition based on analysis is: $5.4 \mathrm{M} \mathrm{Na}^{+}, 0.50 \mathrm{M} \mathrm{NO}_{3}^{-}$, $0.48 \mathrm{M} \mathrm{NO}_{2}^{-}, 4.5 \mathrm{M}^{-}$Total $\mathrm{OH}^{-}$, and $0.2 \mathrm{M} \mathrm{AlO}_{2}^{-}$. The [Tc] measured by ICP-MS (mass 99) was $3.09 \mathrm{mg} / \mathrm{L}$. Prior to the technetium ion exchange tests, the Tank $44 \mathrm{~F}$ sample was treated with monosodium titanate (MST) by batch contact and dead-end filtration to remove strontium and actinides, and crystalline silicotitanate (Ionsiv ${ }^{\oplus} \mathrm{IE}-911$ ) in column configuration to remove cesium. ${ }^{2}$ The $\mathrm{Sr} / \mathrm{Cs}$-decontaminated product was stored in a tank in the High Level Cells Facility at SRTC following the conclusion of these tests. The tank was known to contain small amounts of settled MST. A small sample $(\sim 60 \mathrm{~mL})$ of

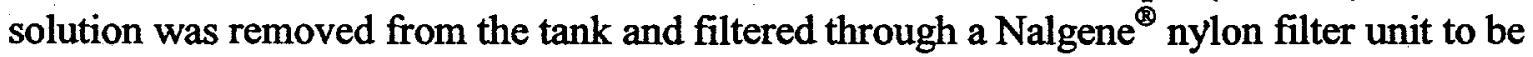
used for the batch contact test. Approximately $35 \mathrm{~L}$ of solution was pumped from the tank and filtered using an in-line 0.45 micron Whatman Polycap ${ }^{8} 75$ TF disposable filter capsule with a polytetrafluoroethylene membrane. The filtered liquid was stored in two polyethylene carboys before being pumped into the SuperLig 639 ion exchange column. The measured density of the solution was $1.202 \mathrm{~g} / \mathrm{mL}$. Sodium hydroxide solutions, 1.0 and $0.1 \mathrm{M}$, were used for column pretreatment and washing, respectively. These solutions were prepared using ACS certified, high-purity $\mathrm{NaOH}$ from Fisher Scientific, Inc. 
Table 2. Sr/Cs-Decontaminated SRS Tank $44 \mathrm{~F}$ Waste Composition

\begin{tabular}{|l|c|}
\hline Chemical & Molarity \\
\hline $\mathrm{Na}^{+}$ & 5.40 \\
\hline $\mathrm{K}^{+}$ & $5.66 \mathrm{E}-02$ \\
\hline $\mathrm{NO}_{3}^{-}$ & $4.95 \mathrm{E}-01$ \\
\hline $\mathrm{NO}_{2}^{-}$ & $4.76 \mathrm{E}-01$ \\
\hline $\mathrm{Total}^{-} \mathrm{OH}^{-}$ & 4.50 \\
\hline $\mathrm{SO}_{4}{ }^{2-}$ & $1.33 \mathrm{E}-03$ \\
\hline $\mathrm{PO}_{4}{ }^{3-}$ & $3.12 \mathrm{E}-03$ \\
\hline $\mathrm{AlO}_{2}{ }^{-}$ & 0.2393 \\
\hline $\mathrm{F}^{-}$ & $3.38 \mathrm{E}-04$ \\
\hline $\mathrm{Cl}^{-}$ & $9.27 \mathrm{E}-03$ \\
\hline $\mathrm{HCOO}^{-}$ & $2.22 \mathrm{E}-3$ \\
\hline $\mathrm{C}_{2} \mathrm{O}_{4}{ }^{2-}$ & $<7.46 \mathrm{E}-4$ \\
\hline
\end{tabular}

The measured Tc-99 and Cs-137 concentrations were $3.089 \mathrm{mg} / \mathrm{L}$ and $1.37 \mu \mathrm{Ci} / \mathrm{mL}$, respectively.

\subsection{Equipment and Procedures}

\subsubsection{Batch Contact Experiments}

Duplicate batch contact tests were performed at ambient temperature using an orbital shaker in the High Level Cells Facility at SRTC. Ion exchange resin $(0.12 \mathrm{~g})$ and Tank $44 \mathrm{~F}$ solution $(13.0-13.5 \mathrm{~mL})$ were transferred to a $21 \mathrm{~mL}$ polyethylene vial and placed on the shaker. The ratio of solution volume to exchanger mass was $\sim 110$. The temperature was measured at the beginning and the end of the experiment (observed range: $25-26^{\circ} \mathrm{C}$ ). After 24.0 hours, the samples were removed from the shaker. The solution was then filtered through a 0.45 micron Nalgene ${ }^{\circledR}$ nylon filter using vacuum. Visual inspection of the resin after filtration indicated that agitation of the vials during the test did not lead to significant material degradation. Portions $(2-4 \mathrm{~mL})$ of the filtrate and similarly-treated samples of the feed solutions (blanks) were analyzed for technetium by the Savannah River Technology Center Analytical Development Section using ICP-MS. Data for the batch contact test is provided in Attachment 1. The Tc distribution coefficient $\left(\mathrm{K}_{\mathrm{d}}\right)$ and \% removal were calculated using the formulas shown in Eqs. 1 and 2 , respectively.

$$
\begin{aligned}
& \mathrm{K}_{d}=\left[\left(C_{i} / C_{f}\right)-1\right]\left[V /\left(M^{*} F\right)\right] \\
& \% \text { removal }=\frac{(100)^{*}\left(C_{i}-C_{f}\right)}{C_{i}}
\end{aligned}
$$


$\mathrm{C}_{\mathrm{i}}=$ initial $[\mathrm{Tc}]$ in feed $(\mathrm{mg} / \mathrm{L})$

$\mathrm{C}_{\mathrm{f}}=$ final $[\mathrm{Tc}]$ after contact $(\mathrm{mg} / \mathrm{L})$

$\mathrm{V}=$ volume of solution used $(\mathrm{mL})$

$\mathrm{M}=$ mass of "as-received" resin (g)

$\mathrm{F}=$ resin dry weight correction factor

An F-factor of $98.7 \%$ was used to calculate the $\mathrm{K}_{d}$ based on the data reported in Table 1 for batch \#981015DHC720011.

\subsubsection{Column Experiments}

Figure 1 shows the ion exchange column design. A photograph of the actual equipment is shown in Figure 2. Although the BNFL design uses a lead and a lag column, a single ion exchange column was used for treating the Tank $44 \mathrm{~F}$ sample, since the primary purpose of this test was to develop the loading profile for the lead column. The ion exchange column was constructed from $2.7 \mathrm{~cm}$ ID sodium borosilicate glass tubing. Decals were affixed to the outer wall of the column with $1 \mathrm{~mm}$ graduations to measure the resin bed height. The outside of the column was coated with a layer of polyvinylchloride to reduce hazards associated with potentially pressurizing the apparatus. A 3-way, Whitey ${ }^{\circledR} 40$ Series stainless steel ball valve (\#1) was attached to the bottom of the columns. The column head was attached to the column using a Rudivis ${ }^{\circledR}$ ground-glass joint. Two 2-way, stainless steel ball valves (\#2 and \#3) were attached on opposite sides of the column head to serve as feed ports. The column head also contained a pressure gauge, a pressure relief valve, and a fill reservoir that also served as a vent. The valves were connected to the columns by high-density polyethylene bushings with Viton ${ }^{\circledR}$ O-rings. Swage-lock ${ }^{\circledR}$ fittings were used to connect the valves to low-density polyethylene tubing (11/64" ID) which served as column feed and effluent lines. Stainless steel wire screens ( $200 \mathrm{mesh}$ ) were inserted into the columns to support the ion exchange resin. All solutions were passed through the columns in the downflow direction using Fluid Metering Incorporated QG150 positive displacement pumps with 1/4 and $3 / 8$-inch piston sizes. Samples were collected manually at the end of the effluent collection line (see Figure 2) rather than with the manual sample port located at the bottom of the column. The manual sample port was only used to drain the liquid head from the column at specific times during column operation as described in the technical task plan. ${ }^{3}$

A $50.6 \mathrm{~mL}$ sample of ion exchange resin was prepared by mixing $11.9889 \mathrm{~g}$ of "asreceived" SuperLig ${ }^{\circledR} 639$ resin batch \#981015DHC720011 and $12.0010 \mathrm{~g}$ of resin batch \#990420DHC720067 in a polyethylene bottle. A 50:50 mixture of these resin batches was also used for pilot-scale simulant column tests conducted at SRTC. ${ }^{4}$ The resin was soaked overnight in deionized water and transferred into the ion exchange column as a suspension. The measured height of the resin bed in the column just after packing of the resin was $8.75 \mathrm{~cm}$ ( 1 column volume $=50.6 \mathrm{~mL}$, based on $2.7 \mathrm{~cm}$ column ID). Quartz wool and glass beads were then added to the top of the resin bed to keep the resin from floating when processing the Tank $44 \mathrm{~F}$ sample. A brief simulant experiment was 
Revision 0

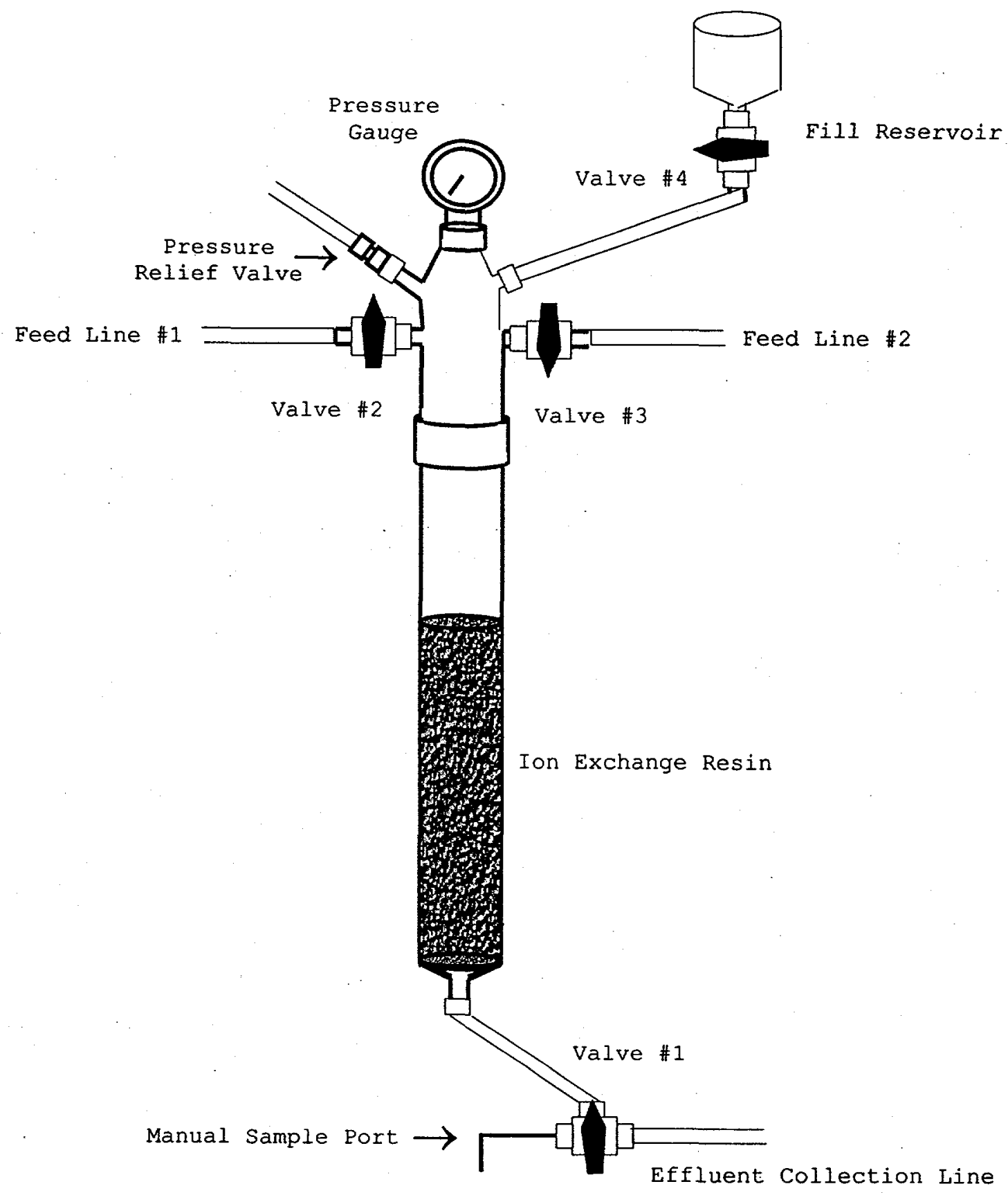

Figure 1. Ion Exchange Column Design 


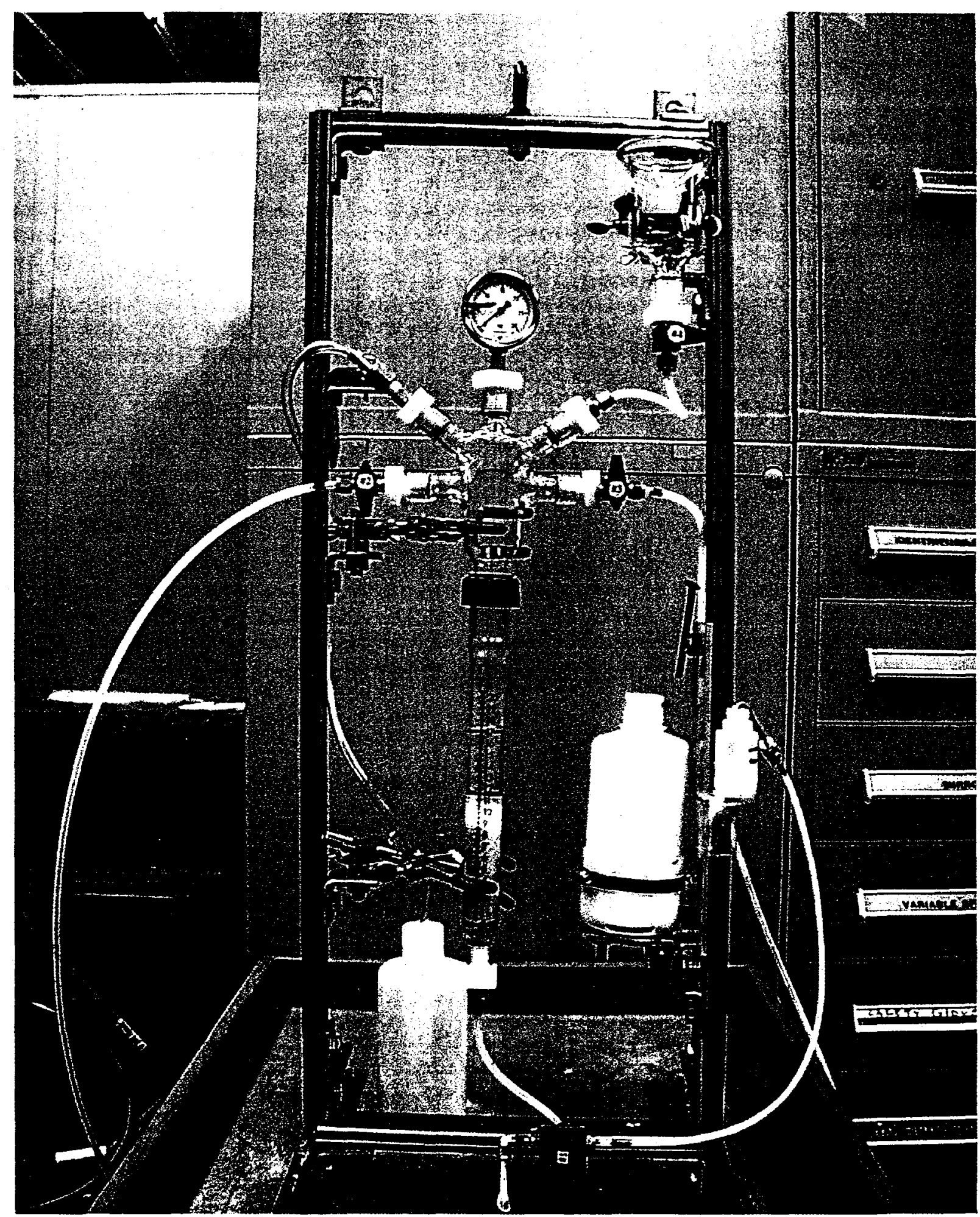

Figure 2. Tank $44 \mathrm{~F}$ Technetium Ion Exchange Column Apparatus 
performed using a simple Tank $44 \mathrm{~F}$ simulant spiked with perrhenate in order to confirm that the column was packed well and would not channel. Approximately $20 \mathrm{CV}$ of simulant was passed through the column. Analysis indicated good column performance with no indication of channeling or early breakthrough of perrhenate. The perrhenate was then thoroughly eluted from the column with water and the column was stored in water for transport to the High Level Cells Facility.

In the High Level Cells, the resin bed was pretreated with 3 column volumes of $1.0 \mathrm{M}$ $\mathrm{NaOH}$ over a 1 hour period just prior to beginning the column experiment (Pretreatment Cycle). The $\mathrm{NaOH}$ liquid level was adjusted so that the volume of liquid above the resin bed was approximately $50 \mathrm{~mL}(\sim 1$ column volume) before Tank $44 \mathrm{~F}$ solution was pumped into the column (see note below). While pumping the Tank $44 \mathrm{~F}$ solution downflow through the column, samples $(10 \mathrm{~mL})$ of effluent were collected approximately every 10 column volumes and the effluent from the column was collected in $1 \mathrm{~L}$ bottles in $\sim 20 \mathrm{CV}$ increments (Feed Cycle). After processing all of the Tank $44 \mathrm{~F}$ solution, the liquid in the column was drained to within approximately $1 \mathrm{~cm}$ of the glass beads located on top of the resin bed. Sodium hydroxide solution $(0.1 \mathrm{M})$ was pumped into the column until the volume of liquid above the resin bed was approximately $50 \mathrm{~mL}$. The exit line was opened and 2.5-3.5 column volumes of $0.1 \mathrm{M} \mathrm{NaOH}$ was passed through the column in one hour and samples of the effluent were collected every 20 minutes $(\mathrm{NaOH}$ Wash Cycle). Wash samples were analyzed for Tc- 99 by ICP-MS, $\mathrm{Na}^{+}$by ICP-ES, and Free $\mathrm{OH}^{-}$. The column was eluted with deionized water at a flow rate of 1 column volume per hour. Every 4 hours $(4 \mathrm{CV})$ a sample was collected and the eluate collection bottle was changed (Elution Cycle). Samples were analyzed for technetium by the Savannah River Technology Center Analytical Development Section using ICP-MS. Data from the column experiment is provided in Attachment 2 . The cell air temperature during the column experiment ranged from $23-27^{\circ} \mathrm{C}$.

The flow rate was monitored during the column experiments by measuring the time required to collect 5-10 mL samples of effluent. At the conclusion of the experiment, the weight of effluent collected in each $1 \mathrm{~L}$ bottle was measured and the volume of the solution was calculated from the density $(1.202 \mathrm{~g} / \mathrm{mL})$. After correction for the volume of samples collected, the flow rate was calculated from the time of collection for each bottle. The overall flow rate was taken to be the average of the flow rates calculated for each collection bottle. The flow rate calculated for the Feed Cycle was $3.1 \mathrm{CV} / \mathrm{hr}$ (superficial velocity: $0.45 \mathrm{~cm} / \mathrm{min}$ ). The minimum and maximum flow rates measured during the Feed Cycle were 2.7 and $3.2 \mathrm{CV} / \mathrm{hr}(0.39$ and $0.46 \mathrm{~cm} / \mathrm{min})$, respectively. The flow rate for the elution cycle was calculated by the same method to give an average flow rate of $0.93 \mathrm{CV} / \mathrm{hr}(0.14 \mathrm{~cm} / \mathrm{min})$. The minimum and maximum flow rates measured during the Elution Cycle were 0.88 and $0.99 \mathrm{CV} / \mathrm{hr}(0.13$ and $0.15 \mathrm{~cm} / \mathrm{min})$, respectively. The number of column volumes of solution processed at each sampling period during column operation was calculated from the time of collection and the flow rate measured for the corresponding collection bottle.

Note: The column operating procedure was designed to emulate the actual plant operation, where the column is half full of resin and half full of liquid. According to the procedure, the initial feed that was pumped into the ion exchange column during the Feed 
Cycle was to be diluted by the $1 \mathrm{CV}$ of $1.0 \mathrm{M} \mathrm{NaOH}$ pretreatment solution which remained above the resin bed. Likewise, the eluting solution was allowed to mix with the liquid head left above the resin from the $\mathrm{NaOH}$ Wash Cycle. No attempt was made to correct for mixing of solutions in the column head-space when calculating the number of column volumes of feed, wash, or eluate processed. The Feed and Elution cycles were considered to start at the moment that the feed and eluent solutions entered the column head. The $\mathrm{NaOH}$ Wash Cycle began at the moment that the valve was opened to the effluent collection line after the liquid head had been reestablished.

\subsection{RESULTS AND DISCUSSION}

\subsection{Batch Contact Experiment}

A $24 \mathrm{hr}$ batch contact experiment was conducted with SuperLig 639 resin batch \#981015DHC720011 in order to determine the resin volume needed for the technetium ion exchange column experiment. The average $\mathrm{K}_{d}$ value calculated from duplicate batch contacts was $950.1 \mathrm{~mL} / \mathrm{g}$ which corresponds to $89.4 \%$ technetium removal. The result indicates that at least $89.4 \%$ of the Tc in the Tank $44 \mathrm{~F}$ sample exists as pertechnetate anion $\left(\mathrm{TcO}_{4}{ }^{-}\right)$and confirms that SuperLig ${ }^{\circledR} 639$ resin efficiently removes technetium from Tank $44 \mathrm{~F}$ waste during batch contact.

A rough estimate of the 50\% Tc breakthrough point in SuperLig ${ }^{\otimes} 639$ (batch \#981015DHC720011) ion exchange columns can be predicted from the $K_{d}$ and the bulk resin density. The bulk resin density for batch \#981015DHC720011 was reported by SRTC to be $0.489 \mathrm{~g} / \mathrm{mL}$. ${ }^{1}$ The number of column volumes of feed estimated to reach $50 \%$ Tc breakthrough $(\lambda)$ can be calculated using Eq. 3.

$$
\lambda=\left(\mathrm{K}_{\mathrm{d}}\right) \times \text { (bulk resin density) }
$$

The $\lambda$ value calculated with Eq. 3 is $465 \mathrm{CV}$. Based on the $\lambda$ value and the volume of solution to be processed it was decided to use $\sim 50 \mathrm{~mL}$ of resin for the column experiments. The $50 \%$ Tc breakthrough point would be expected after processing $\sim 23 \mathrm{~L}$ of Tank $44 \mathrm{~F}$ solution with a $50 \mathrm{~mL}$ bed of SuperLig ${ }^{\circledR} 639$ resin (batch \#981015DHC720011).

\subsection{Column Experiment}

Results from the column experiment performed with the $50.6 \mathrm{~mL}$ SuperLig ${ }^{\circledR} 639$ resin bed and $\mathrm{Sr} / \mathrm{Cs}$-decontaminated Tank $44 \mathrm{~F}$ solution are shown in Figure 3. A 50:50 mixture (by as-received weight) of resin batches $981015 \mathrm{DHC} 720011$ and 990420 DHC720067 was used to prepare the column. Based on previous simulant batch contact experiments performed on these SuperLig ${ }^{\circledR} 639$ resin batches, better column performance was expected than predicted by the $\lambda$ calculation above. ${ }^{5}$ Perrhenate anion $\left(\mathrm{ReO}_{4}{ }^{-}\right) \mathrm{K}_{d}$ values measured for batch \#990420DHC720067 at a Re feed concentration of 


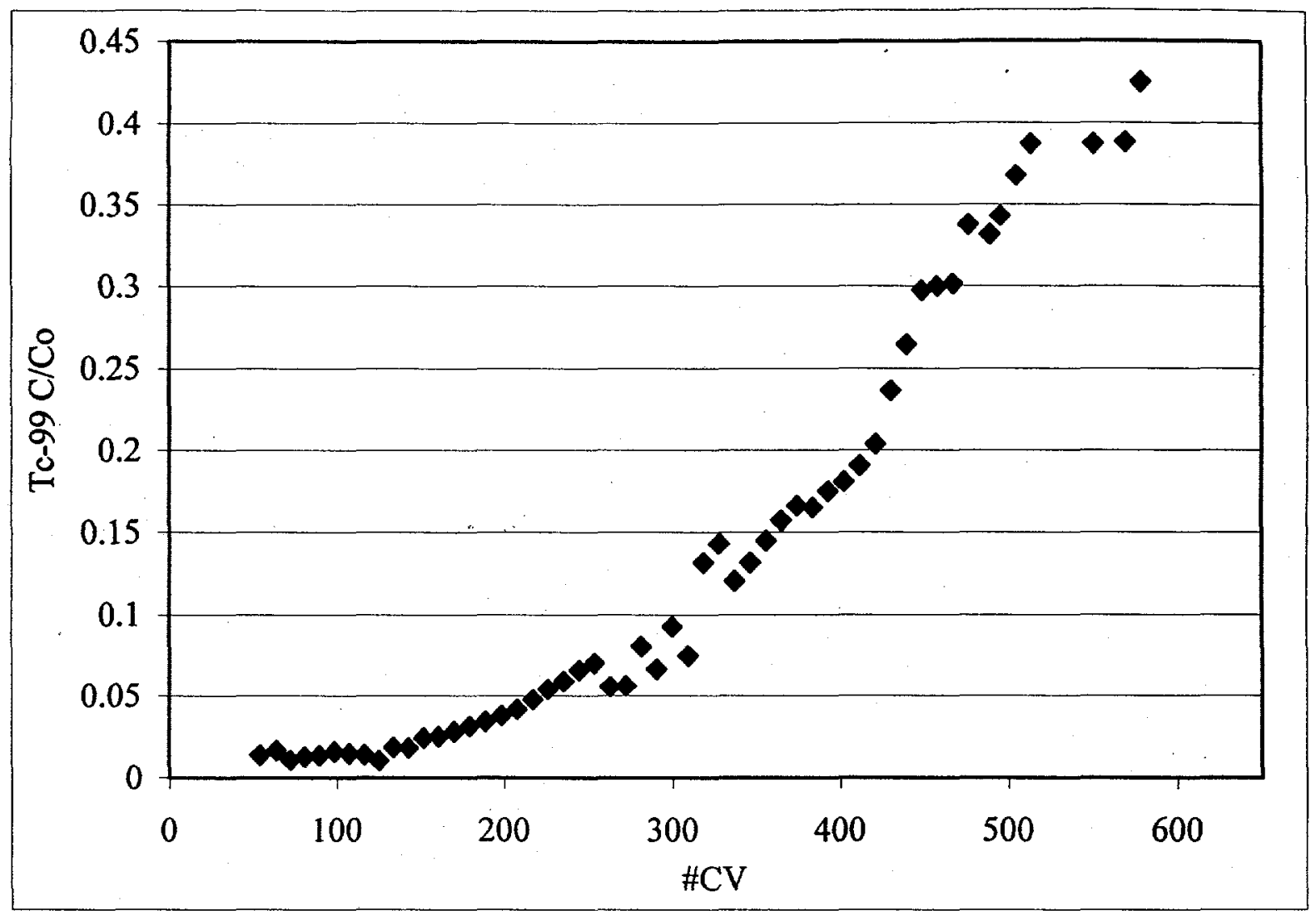

Figure 3. SuperLig ${ }^{\circledR} 639$ Column Technetium Breakthrough Profile with SRS Tank $44 \mathrm{~F}$ Solution (resin batches: $981015 \mathrm{DHC} 720011$ and $990420 \mathrm{DHC} 720067$, flow rate: $3 \mathrm{CV} / \mathrm{hr}$, $\mathrm{T}=23-27^{\circ} \mathrm{C}$.)

3.8 E-5 M (Hanford Env. A simulant) were $31 \%$ higher than those observed for batch \#981015DHC720011 at a similar initial Re concentration. (The [Tc] in the Sr/Csdecontaminated Tank $44 \mathrm{~F}$ waste was $3.1 \mathrm{E}-5 \mathrm{M}$.) At a feed flow rate near $3 \mathrm{CV} / \mathrm{hr}$, $\sim 45 \% \mathrm{Tc}$ breakthrough was observed after $579 \mathrm{CV}(29.3 \mathrm{~L})$ of Tank $44 \mathrm{~F}$ solution had been processed. This result is consistent with the $50 \% \mathrm{Tc}$ breakthrough that would be expected after increasing the calculated $\lambda$ value above by $15.6 \%\left(\lambda_{\text {corr }}=(465) \times(1.156)\right.$ $=538 \mathrm{CV}$ ) due to the higher measured capacity of SuperLig ${ }^{\otimes} 639$ batch \#990420DHC720067. (Note: An additional 8 CV of Tank $44 \mathrm{~F}$ solution was processed prior to stopping the Feed Cycle, but no additional samples were collected for analysis. The total volume of Tank $44 \mathrm{~F}$ solution processed was $29.7 \mathrm{~L}$ or $587 \mathrm{CV}$.) The lower than expected Tc-99 C/Co values observed at $260-320 \mathrm{CV}$ and 550-570 CV cannot be explained based on any processing anomalies. Integration of the Tc breakthrough curve in Figure 3 indicates that approximately $78 \mathrm{mg}$ of Tc were adsorbed onto the resin during the Feed Cycle out of a total of $91 \mathrm{mg}$ of $\mathrm{Tc}$ in the feed solution. This corresponds to a decontamination factor of 7.1 for the single column. Note: The sample appears to contain very little material with an atomic mass of 99 that cannot be removed by the resin. The first effluent sample, which was collected after $54 \mathrm{CV}$ of solution were processed, contains $0.0436 \mathrm{mg} / \mathrm{L}$ of a mass 99 element, which is $1.4 \%$ of the initial concentration. Theoretically, this could be pertechnetate, a non-pertechnetate form of technetium, or Ru-99. 
Following the Feed Cycle, the liquid head was drained from the column and then reestablished with $1 \mathrm{CV}$ of $0.1 \mathrm{M} \mathrm{NaOH}$. The column was washed with $3 \mathrm{CV}$ of $0.1 \mathrm{M}$ $\mathrm{NaOH}$ over a 1 hour period. The effluent during the Wash Cycle was collected in approximately $1 \mathrm{CV}$ increments and analyzed for Tc-99, $\mathrm{Na}^{+}$and Free $\mathrm{OH}^{-}$. Analysis results are shown in Table 3 . The results reveal that $\mathrm{Tc}$ begins to elute from the column during the $\mathrm{NaOH}$ wash. The [Tc] in the first $\mathrm{CV}$ of wash solution collected $(1.8 \mathrm{mg} / \mathrm{L}$ Tc-99) is comparable to the last effluent samples analyzed during the Feed Cycle $(\sim 1.3$ $\mathrm{mg} / \mathrm{L}$ Tc-99). The [Tc] in the second and third wash fractions gradually increased to 2.8 $\mathrm{mg} / \mathrm{L}$, which approaches the feed $\mathrm{Tc}$ concentration $(3.1 \mathrm{mg} / \mathrm{L})$. However, the total amount of Tc-99 removed from the column during the $0.1 \mathrm{M} \mathrm{NaOH}$ feed displacement was only $\sim 0.35 \mathrm{mg}$ or $0.45 \%$ of the total Tc-99 estimated to be loaded onto the resin. As expected, the $\mathrm{Na}^{+}$and free $\mathrm{OH}^{-}$concentrations decrease in successive wash fractions to 0.34 and $0.21 \mathrm{M}$, respectively. These values approach the initial concentrations of these species in the $0.1 \mathrm{M} \mathrm{NaOH}$ wash solution.

Table 3. Characterization of SuperLig ${ }^{\otimes} 639$ Column Post-Feed 0.1 M NaOH Wash Solutions

\begin{tabular}{|c|c|c|c|c|c|}
\hline $\mathrm{CV}$ & Tc-99 (mg/L) & $\mathrm{Na}^{+}(\mathrm{M})$ & Free $\mathrm{OH}^{-}(\mathrm{M})$ & Te99 (mg) & Te99 Loss \\
\hline 1 & 1.774 & 5.06 & 3.68 & 0.09 & $0.12 \%$ \\
\hline 2 & 2.365 & 2.26 & 1.53 & 0.12 & $0.15 \%$ \\
\hline 3 & 2.755 & 0.339 & 0.211 & 0.139 & $0.18 \%$ \\
\hline
\end{tabular}

Figures 4 and 5 show the Tc elution profile resulting from elution of the column with deionized water at a flow rate of $1 \mathrm{CV} / \mathrm{hr}$. Analysis indicated that the Tc concentration in the eluate peaked after 4-7 CV of eluate had been collected. The actual peak in the Tc concentration is uncertain since eluate samples were only collected at $\sim 4 \mathrm{CV}$ intervals. The pertechnetate elution peak is consistent with perrhenate elution profiles observed with simulated Hanford Envelope A solutions and SuperLig ${ }^{\circledR} 639$ resin (Re eluate peak concentrations: $2-5 \mathrm{CV}$ ). ${ }^{5}$ The majority of the Tc eluted from the column in the first 12 $\mathrm{CV}$ of eluate and then the [Tc] gradually decreased. The Tc concentration in the eluate did not reach the plant design criteria of $1 \%$ of the feed until approximately $50 \mathrm{CV}$ of eluate had been processed. The column was stored in deionized water at the conclusion of the elution.

After the completion of the column experiment, the first $37.3 \mathrm{CV}$ of Tc eluate were combined in a single polyethylene carboy and the solution was allowed to mix for several days. The remaining $\sim 15 \mathrm{CV}$ of eluate contained an estimated $0.1 \mathrm{mg}$ of $\mathrm{Tc}$ based on integrating the elution data presented in Figure 5. Since this amount of $\mathrm{Tc}$ is not significant, little error was introduced by analyzing only the first $37.3 \mathrm{CV}$ of eluate. Attachment 3 shows the analysis results for the composited eluate. Based on ICP-MS analysis, the eluate (total volume: $\sim 1.83 \mathrm{~L}$; Note: The total eluate volume is less than 37.3 $\mathrm{CV}$ due to the volume of samples collected.) contained $\sim 41.6 \mathrm{mg} / \mathrm{L} \mathrm{Tc}$ which corresponds to a total of $76 \mathrm{mg} \mathrm{Tc}$ ( $97.5 \%$ of the total Tc adsorbed on the resin during the Feed Cycle). There is moderate agreement $(\sim 15 \%)$ between the ICP-MS and ICP-ES 


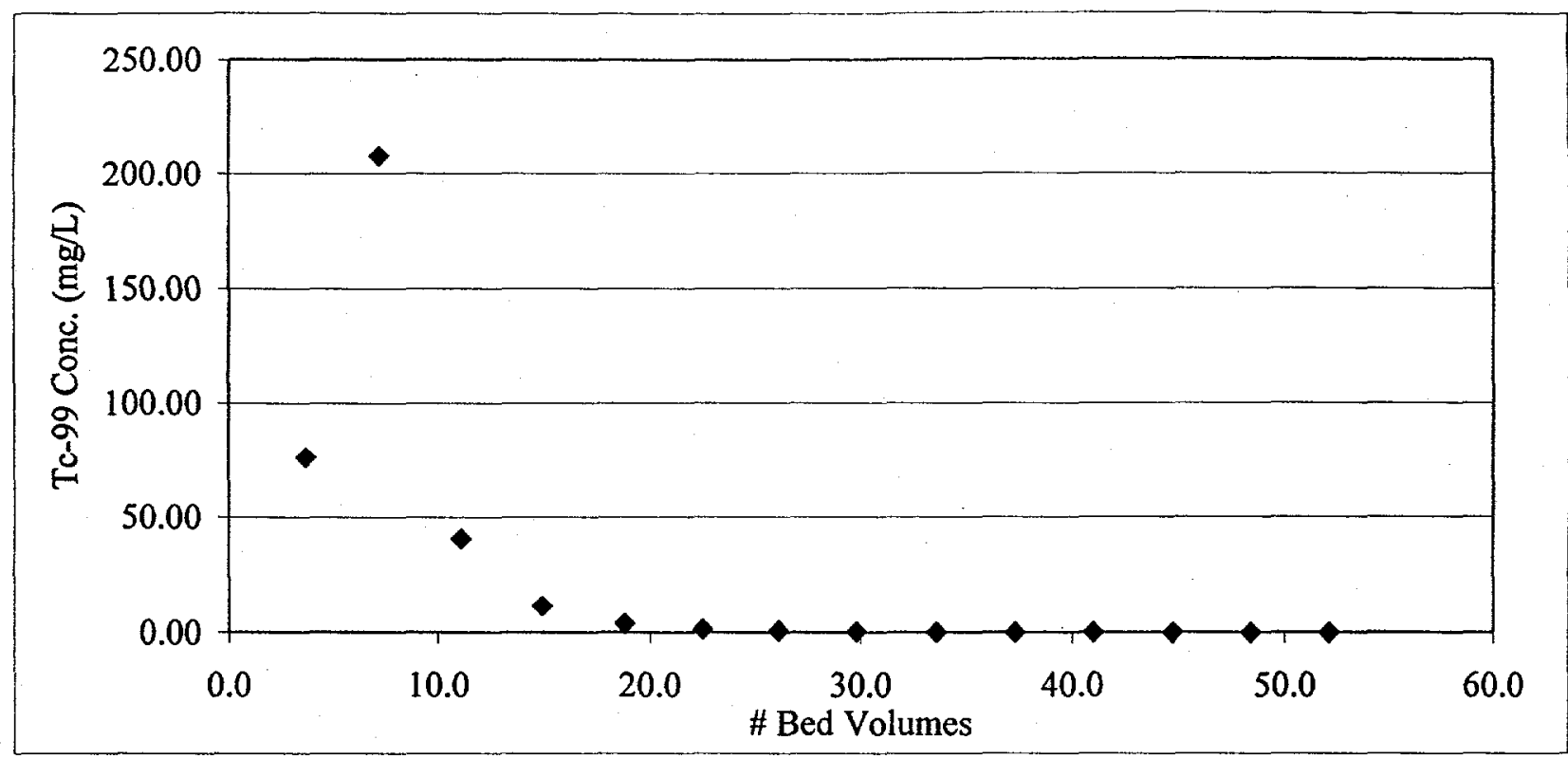

Figure 4. SuperLig ${ }^{\circledR} 639$ Column Technetium Elution Profile with SRS Tank $44 \mathrm{~F}$ Solution (resin batches: 981015DHC720011 and 990420DHC720067, eluent: water, flow rate: $1 \mathrm{CV} / \mathrm{hr}, \mathrm{T}=23-27^{\circ} \mathrm{C}$.)

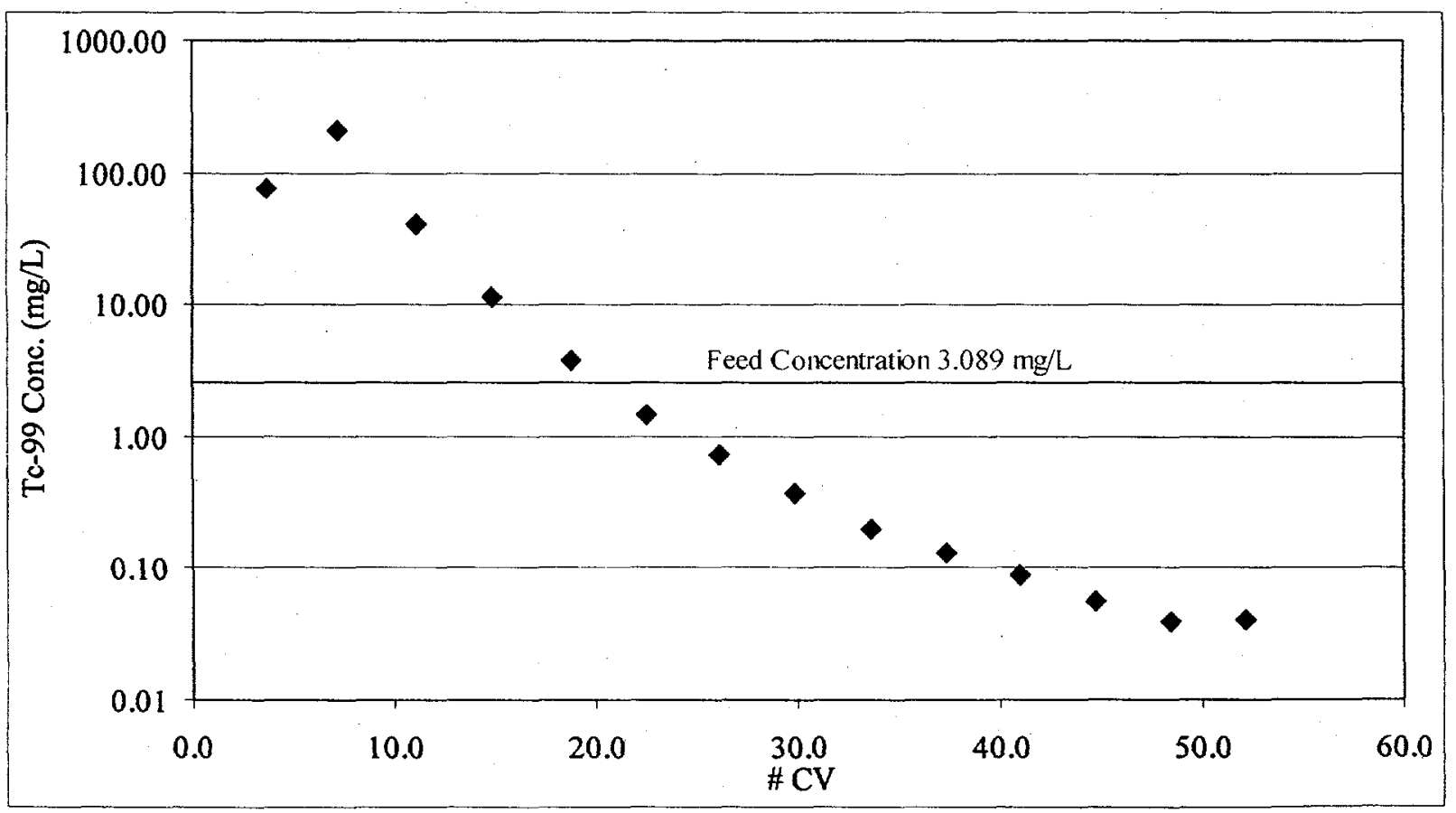

Figure 5. SuperLig ${ }^{\circledR} 639$ Column Technetium Elution Profile with SRS Tank 44 F Solution Semi-Log Plot (resin batches: 981015DHC720011 and 990420DHC720067, eluent: water, flow rate: $1 \mathrm{CV} / \mathrm{hr}, \mathrm{T}=23-27^{\circ} \mathrm{C}$.) 
analyses of the Tc in the eluate (41.6 vs. $35.5 \mathrm{mg} / \mathrm{L}$, respectively). Use of ICP-ES for Tc analysis has been developed at SRTC for this program. In general, consistent analysis results were observed between duplicate samples for all analysis techniques. However, chloride ion concentration in the eluate varied considerably between the two analysis techniques used. Ion chromatography (IC) analysis indicated that chloride levels were $<500 \mathrm{mg} / \mathrm{L}$. In contrast, ion selective electrode (ISE) analysis indicated that the chloride concentration was near $1150 \mathrm{mg} / \mathrm{L}\left(2101 \mathrm{mg} \mathrm{Cl}^{-}\right)$, which corresponds to $\sim 22 \%$ of the total chloride in the feed. No chloride analysis was conducted on the column effluent. These observations indicate that chloride anion may be concentrated by the technetium ion exchange resin, but the analysis techniques in these complex mixtures are variable. Alternatively, the "as-received" SuperLig ${ }^{\circledR} 639$ resin may have contained residual chloride ion which leached off during the water elution. High chloride ion concentration in SuperLig ${ }^{\circledR} 639$ technetium eluates has been reported previously for ion exchange column experiments performed on Hanford waste supernates. ${ }^{6}$ It is also noted that silicon is concentrated by the resin. This may be attributable to high Si concentrations in the feed due to leaching from Ionsiv ${ }^{\circledR}$ IE-911. Alternatively, the Si concentration may have been high in the original Tank $44 \mathrm{~F}$ sample, prior to treatment with Ionsiv ${ }^{\circledR}$ IE-911.

After analysis of the eluate samples confirmed that the column had been fully eluted, the water storage solution was drained from the column and the resin was partially dried by purging the system with compressed air. The column head was removed and resin samples were collected from the top of the bed. Duplicate samples of resin particles were submitted for analysis along with two samples of "as-received" resin. All resin samples were dissolved by acid digestion and analyzed by ICP-ES. Analysis results are shown in Attachment 4. In general, the analysis results for the resin used in the Tank $44 \mathrm{~F}$ column experiment were similar to the results for the "as-received" resin. The sodium weight \% was higher by a factor of $\sim 5.5$ for the resin used in the column experiment relative to the "as-received resin". The lead content reported for the "as-received" resin is higher than expected, but the value reported $(\sim 0.1 \mathrm{wt} . \%)$ is very near the minimum detection limit. ICP-ES results reported for additional samples of "as-received" resin which were digested and analyzed at a lower dilution factor, indicated that the lead content was less than 0.0050 wt. \% (Attachment 4). Similar results were observed for several other metals. These observations are corroborated by analyses of "as-received" resin at Pacific Northwest National Laboratory. ${ }^{7}$ It is concluded that the high values reported for these metals were an artifact of the large dilution of the sample and are not accurate. Most importantly, no measurable amounts of Tc were found in the resin samples from the column experiment.

\subsection{CONCLUSIONS}

Batch contact and column tests completed on the Sr/Cs-decontaminated SRS Tank $44 \mathrm{~F}$ supernate confirmed that SuperLig ${ }^{\circledR} 639$ resin efficiently removes technetium from this solution. The observed column performance far exceeds the current plant design criteria, which requires a minimum of $100 \mathrm{CV}$ of feed to be processed prior to elution and regeneration. (The current BNFL design criteria utilizes two columns in a lead/lag 
configuration and required column regeneration at $50 \% \mathrm{Tc}$ breakthrough from the lead column.) However, synthesis of the resin should be modified to increase the density to avoid floating the resin bed while processing these dense feed solutions. Additional research is also needed to identify the manufacturing variables that affect resin capacity and develop methods for its optimization. The column was effectively eluted with water at a flow rate of $1 \mathrm{CV} / \mathrm{hr}$. Further work is needed to evaluate methods for reducing column elution duration and volume. These may include heating the water used for elution (as recommended by IBC personnel), slowing the elution flow rate after the first several column volumes, or periodically stopping the flow during the elution to allow the resin to continue to desorb technetium without generating more eluate volume. 


\subsection{DESIGN CHECK}
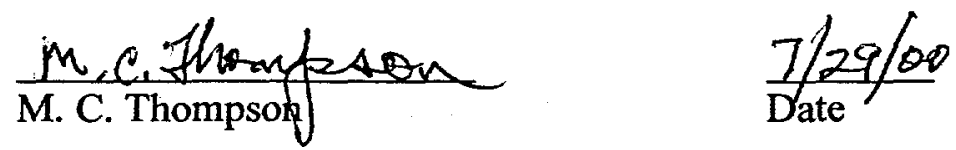

\subsection{QUALITY ASSURANCE}

McCabe, D. J. Intermediate Scale Radioactive Ion Exchange Task Technical and Quality Assurance Plan (U), BNF-003-98-0165, Rev. 0.

\subsection{REFERENCES}

1. Hassan, N. M.; King, W. D.; McCabe, D. J., SuperLig ${ }^{\circledR}$ Ion Exchange Resin Swelling and Bouyancy Study (U), BNF-003-98-0051, Rev. 0.

2. Walker, D. D, Cesium Removal From Savannah River Site Radioactive Waste Using Crystalline Silicotitanate (IONSIV IE-911), WSRC-TR-99-00308, Rev.0.

3. McCabe, D. J. Intermediate-Scale Radioactive Ion Exchange Task Technical and Quality Assurance Plan (U), BNF-003-98-0165, Rev. 0.

4. Steimke, J. L. et al, Summary of Testing of SuperLig 639 at the TFL Ion Exchange Facility $(U)$, BNF-003-98-0153, Rev. 0.

5. King, W. D.; McCabe, D. J.; Hassan, N. M., Evaluation of SuperLig ${ }^{\circledR} 639$ Ion Exchange Resin for the Removal of Perrhenate Ion from Hanford Envelope $A$ Simulant $(U)$, BNF-003-98-0140, Rev. 0.

6. Hassan, N. M.; McCabe, D. J.; King, W. D. Small-Scale Ion Exchange Removal of Cesium and Technetium from Hanford Tank 241-AN-102, BNF-003-98-0219, Rev. 0 .

7. Kurath, D. E.; Wagner, J. J. Analysis of Spent Ion Exchange Media: SuperLig ${ }^{\circledR} 639$ and SuperLig ${ }^{\circledR}$ 644, PNWD-3037/BNFL-RPT-028, Rev. 0. 


\section{DISTRIBUTION:}

M. A. Norato, 786-5A

N. M. Hassan, 773-A

D. Kurath, PNNL

M. E. Johnson, BNFL, Inc.

W. D. King, 773-42A

D. J. McCabe, 773-42A

J. L. Steimke, 786-5A

H. F. Sturm, 773-A

M. C. Thompson, 773-A

S. T. Wach, 773-42A

D. D. Walker, 773-A

L. Hamm, 773-42A

BNFL Part B Document File, T. Baxter, 773-A 


\subsection{APPENDIX}

8.1 Attachment 1. SuperLig ${ }^{\circledR} 639$ Batch Contact Data

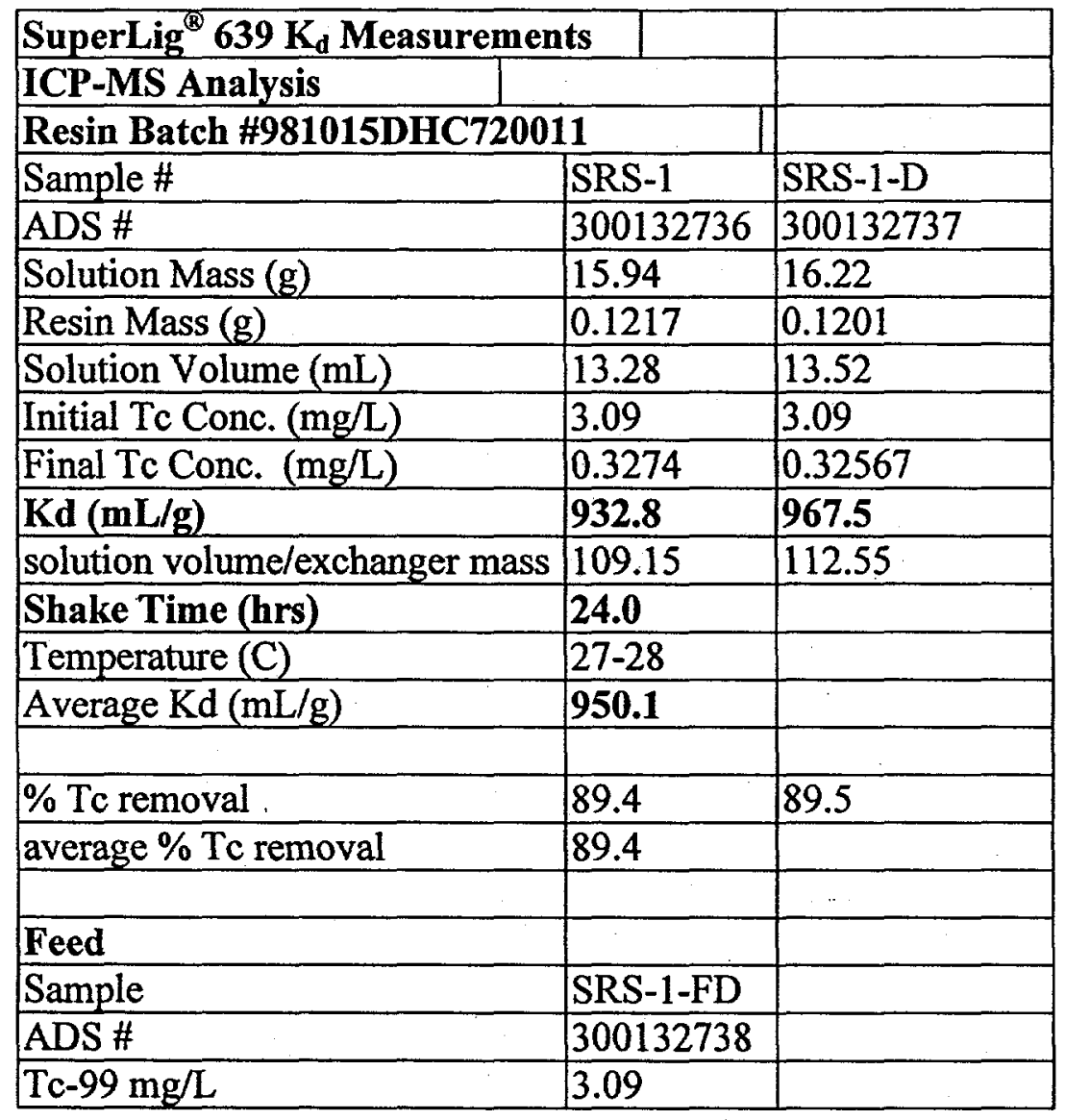




\subsection{Attachment 2. SuperLig ${ }^{\circledR} 639$ Column Data}

Feed Cycle (ICP-MS Analysis)

$\mathrm{Co}_{0}=3.1 \mathrm{mg} / \mathrm{L} \mathrm{Tc}-99$

\begin{tabular}{|c|c|c|c|c|c|c|c|c|c|c|}
\hline ADS \# & $3-134403$ & 3-134404 & $3-134405$ & $3-134406$ & $3-134407$ & 3-134408 & $3-134409$ & $3-134410$ & 3-134411 & $3-134412$ \\
\hline $\mathrm{mg} / \mathrm{L}$ (Tc-99) & 0.04361 & 0.05267 & 0.03390 & 0.04042 & 0.04317 & 0.04986 & 0.04669 & 0.04453 & 0.03351 & 0.05785 \\
\hline$\# \mathrm{CV}$ & 54.0 & 63.8 & 72.0 & 80.7 & 89.7 & 98.6 & 107.4 & 116.3 & 125.1 & 134.0 \\
\hline $\mathrm{C} / \mathrm{Co}$ (Tc-99) & 0.014 & 0.017 & 0.011 & 0.013 & 0.014 & 0.016 & 0.015 & 0.014 & 0.011 & 0.019 \\
\hline ADS \# & $3-134413$ & $3-134414$ & 3-134415 & $3-134416$ & 3-134417 & $3-134418$ & $3-134419$ & $3-134420$ & $3-134421$ & $3-134422$ \\
\hline $\mathrm{mg} / \mathrm{L}$ (Tc-99) & 0.05718 & 0.07576 & 0.07890 & 0.08757 & 0.09757 & 0.10645 & 0.11754 & 0.12948 & 0.14815 & 0.16787 \\
\hline \#CV & 142.8 & 151.9 & 161.0 & 170.2 & 179.4 & 188.8 & 198.3 & 207.5 & 216.7 & 225.9 \\
\hline $\mathrm{C} / \mathrm{Co}$ (Tc-99) & 0.018 & 0.024 & 0.025 & 0.028 & 0.031 & 0.034 & 0.038 & 0.042 & 0.048 & 0.054 \\
\hline$\overline{\mathrm{ADS}} \#$ & $3-134423$ & $3-134424$ & $3-134425$ & $3-134426$ & $3-134427$ & $3-134428$ & $3-134429$ & $3-134430$ & $3-134431$ & $3-134432$ \\
\hline $\mathrm{mg} / \mathrm{L}$ (Tc-99) & 0.18317 & 0.20364 & 0.21771 & 0.17298 & 0.17450 & 0.24934 & 0.20615 & 0.28745 & 0.23195 & 0.40778 \\
\hline \#CV & 235.1 & 244.2 & 253.3 & 262.7 & 272.1 & 281.2 & 290.4 & 299.8 & 309.1 & 318.4 \\
\hline $\mathrm{C} / \mathrm{Co}$ (Tc-99) & 0.059 & 0.066 & 0.070 & 0.056 & 0.056 & 0.080 & 0.067 & 0.093 & 0.075 & 0.132 \\
\hline ADS \# & $3-134433$ & $3-134434$ & $3-134435$ & $3-134436$ & $3-134437$ & $3-134438$ & $3-134439$ & $3-134440$ & $3-134441$ & $3-134442$ \\
\hline $\mathrm{mg} / \mathrm{L}(\mathrm{Tc}-99)$ & 0.44362 & 0.37310 & 0.40770 & 0.44875 & 0.48767 & 0.51517 & 0.51168 & 0.54334 & 0.56153 & 0.59163 \\
\hline$\# \mathrm{CV}$ & 327.7 & 336.9 & 346.1 & 355.5 & 365.0 & 374.3 & 383.6 & 392.9 & 402.1 & 411.6 \\
\hline $\mathrm{C} / \mathrm{Co}$ (Tc-99) & 0.143 & 0.120 & 0.132 & 0.145 & 0.157 & 0.166 & 0.165 & 0.175 & 0.181 & 0.191 \\
\hline ADS \# & $3-134443$ & 3-134444 & $3-134445$ & $3-134446$ & $3-134447$ & $3-134448$ & $3-134449$ & $3-134450$ & $3-134451$ & $3-134452$ \\
\hline $\mathrm{mg} / \mathrm{L}$ (Tc-99) & 0.63235 & 0.73237 & 0.81977 & 0.92183 & 0.93025 & 0.93441 & 1.04700 & 1.02883 & 1.06327 & 1.14033 \\
\hline \#CV & 421.2 & 430.5 & 439.8 & 448.8 & 457.9 & 467.2 & 476.5 & 489.4 & 495.4 & 504.8 \\
\hline $\mathrm{C} / \mathrm{Co}(\mathrm{Tc}-99)$ & 0.204 & 0.236 & 0.264 & 0.297 & 0.300 & 0.301 & 0.338 & 0.332 & 0.343 & 0.368 \\
\hline$\widehat{A D S H}$ & $3-134453$ & $3-134734$ & $3-134736$ & $3-134737$ & & & & & & \\
\hline $\mathrm{mg} / \mathrm{L}$ (Tc-99) & 1.20036 & 1.20036 & 1.20408 & 1.31804 & & & & & & \\
\hline$\# \mathrm{CV}$ & 513.9 & 550.8 & 569.7 & 578.8 & & & & & & \\
\hline $\mathrm{C} / \mathrm{Co}$ (Tc-99) & 0.387 & 0.387 & 0.388 & 0.425 & & & & & & \\
\hline
\end{tabular}

Elution Cycle (ICP-MS Analysis)

Co $=3.1 \mathrm{mg} / \mathrm{L} \mathrm{Tc}-99$

\begin{tabular}{|l|c|c|c|c|c|c|c|c|c|c|}
\hline ADS \# & $3-134460$ & $3-134461$ & $3-134462$ & $3-134463$ & $3-134464$ & $3-134465$ & $3-134466$ & $3-134467$ & $3-134468$ & $3-134469$ \\
\hline mg/L (Tc-99) & 686.6590 & 661.3620 & 40.6290 & 11.5350 & 3.8281 & 1.4623 & 0.7472 & 0.3796 & 0.1978 & 0.1333 \\
\hline C/Co (Tc-99) & 221.503 & 213.343 & 13.106 & 3.721 & 1.235 & 0.475 & 0.243 & 0.123 & 0.064 & 0.043 \\
\hline \# CV & 3.7 & 7.2 & 11.1 & 14.9 & 18.8 & 22.5 & 26.1 & 29.8 & 33.6 & 37.3 \\
\hline & & & & & & & & & & \\
\hline ADS \# & $3-134470$ & $3-134471$ & $3-134472$ & $3-134473$ & & & & & & \\
\hline mg/L (Tc-99) & 0.0895 & 0.0570 & 0.0398 & 0.0403 & & & & & & \\
\hline C/Co (Tc-99) & 0.029 & 0.018 & 0.013 & 0.013 & & & & & & \\
\hline \# CV & 41 & 44.7 & 48.4 & 52.1 & & & & & & \\
\hline
\end{tabular}




\subsection{Attachment 3. Characterization of the Composited Tc Eluate}

\section{ICP-ES Analysis}

\begin{tabular}{|l|c|c|}
\hline ADS \# & $\mathbf{3 0 0 1 4 0 3 9 3}$ & $\mathbf{3 0 0 1 4 0 3 9 4}$ \\
\hline & $\mathbf{m g} / \mathbf{L}$ & $\mathbf{m g} / \mathbf{L}$ \\
\hline $\mathrm{Al}$ & $<12$ & $<12$ \\
\hline $\mathrm{B}$ & 7.50 & 6.80 \\
\hline $\mathrm{Ba}$ & $<1$ & $<1$ \\
\hline $\mathrm{Ca}$ & $<0.5$ & $<0.5$ \\
\hline $\mathrm{Cd}$ & $<1.5$ & $<1.5$ \\
\hline $\mathrm{Co}$ & $<2.5$ & $<2.5$ \\
\hline $\mathrm{Cr}$ & $<3.5$ & $<3.5$ \\
\hline $\mathrm{Cu}$ & $<1.5$ & $<1.5$ \\
\hline $\mathrm{Fe}$ & $<1.5$ & $<1.5$ \\
\hline $\mathrm{La}$ & $<5.5$ & $<5.5$ \\
\hline $\mathrm{Li}$ & $<1$ & $<1$ \\
\hline $\mathrm{Mg}$ & $<0.5$ & $<0.5$ \\
\hline $\mathrm{Mn}$ & $<0.5$ & $<0.5$ \\
\hline $\mathrm{Mo}$ & $<3$ & $<3$ \\
\hline $\mathrm{Na}$ & 283.00 & 213.40 \\
\hline $\mathrm{Ni}$ & $<3.5$ & $<3.5$ \\
\hline $\mathrm{P}$ & $<13$ & $<13$ \\
\hline $\mathrm{Pb}$ & $<14$ & $<14$ \\
\hline $\mathrm{Si}$ & 180.75 & 178.50 \\
\hline $\mathrm{Sn}$ & $<7.5$ & $<7.5$ \\
\hline $\mathrm{Sr}$ & $<0.5$ & $<0.5$ \\
\hline $\mathrm{Sc}$ & $<8.5$ & $<8.5$ \\
\hline $\mathrm{Tc}$ & 36.10 & 34.85 \\
\hline $\mathrm{Ti}$ & $<1$ & $<1$ \\
\hline $\mathrm{V}$ & $<1.5$ & $<1.5$ \\
\hline $\mathrm{Zn}$ & 2.05 & 1.55 \\
\hline $\mathrm{Zr}$ & 2.30 & $<2$ \\
\hline $\mathrm{RadCh}$ & & \\
\hline
\end{tabular}

RadChem

\begin{tabular}{|l|c|c|}
\hline ADS \# & 300140397 & 300140398 \\
\hline $\mathrm{Cs}-137(\mathrm{uCi} / \mathrm{mL})$ & 0.0145 & 0.01628 \\
\hline $\mathrm{Pu}-239 / 240(\mathrm{uCi} / \mathrm{mL})$ & $5.65 \mathrm{E}-04$ & $3.22 \mathrm{E}-04$ \\
\hline $\mathrm{Pu}-238(\mathrm{uCi} / \mathrm{mL})$ & $3.31 \mathrm{E}-04$ & $2.41 \mathrm{E}-04$ \\
\hline $\mathrm{Am}-241(\mathrm{uCi} / \mathrm{mL})$ & $2.15 \mathrm{E}-03$ & $1.52 \mathrm{E}-03$ \\
\hline $\mathrm{Cm}-244(\mathrm{uCi} / \mathrm{mL})$ & $6.78 \mathrm{E}-04$ & $1.28 \mathrm{E}-03$ \\
\hline $\mathrm{Sr}-90(\mathrm{uCi} / \mathrm{mL})$ & $3.40 \mathrm{E}-03$ & $3.29 \mathrm{E}-03$ \\
\hline
\end{tabular}


BNF-003-98-230

Revision 0

Attachment 3. Cont.

IC Anion

\begin{tabular}{|l|c|c|}
\hline $\mathrm{ADS} \#$ & $\mathbf{3 0 0 1 4 0 3 9 5}$ & $\mathbf{3 0 0 1 4 0 3 9 6}$ \\
\hline $\mathrm{F}^{-}(\mathrm{mg} / \mathrm{L})$ & $<100$ & $<100$ \\
\hline $\mathrm{Cl}^{-}(\mathrm{mg} / \mathrm{L})$ & $<500$ & $<500$ \\
\hline $\mathrm{NO}_{3}^{-}(\mathrm{mg} / \mathrm{L})$ & $<100$ & $<100$ \\
\hline $\mathrm{NO}_{2}-(\mathrm{mg} / \mathrm{L})$ & $<500$ & $<500$ \\
\hline $\mathrm{PO}_{4}{ }^{3-}(\mathrm{mg} / \mathrm{L})$ & $<500$ & $<500$ \\
\hline $\mathrm{SO}_{4}{ }^{2-}(\mathrm{mg} / \mathrm{L})$ & $<500$ & $<500$ \\
\hline $\mathrm{C}_{2} \mathrm{O}_{4}^{-}(\mathrm{mg} / \mathrm{L})$ & $<250$ & $<250$ \\
\hline $\mathrm{HCOO}^{-}(\mathrm{mg} / \mathrm{L})$ & $<500$ & $<500$ \\
\hline
\end{tabular}

ISE

\begin{tabular}{|l|c|c|}
\hline ADS \# & $\mathbf{3 0 0 1 4 0 3 9 5}$ & $\mathbf{3 0 0 1 4 0 3 9 6}$ \\
\hline F- (mg/L) & $<500$ & $<500$ \\
\hline $\mathrm{Cl}-(\mathrm{mg} / \mathrm{L})$ & 1200 & 1100 \\
\hline
\end{tabular}

ICP-MS

\begin{tabular}{|l|c|c|}
\hline ADS \# & $\mathbf{3 0 0 1 4 0 3 9 3}$ & $\mathbf{3 0 0 1 4 0 3 9 4}$ \\
\hline mass 99 (mg/L) & 41.958 & 41.275 \\
\hline mass 238 (mg/L) & 0.086 & 0.054 \\
\hline
\end{tabular}

TIC/TOC

\begin{tabular}{|l|c|c|}
\hline ADS \# & $\mathbf{3 0 0 1 4 0 3 9 5}$ & $\mathbf{3 0 0 1 4 0 3 9 6}$ \\
\hline TIC $(\mathrm{mg} / \mathrm{L})$ & 85.5 & 80 \\
\hline TOC $(\mathrm{mg} / \mathrm{L})$ & 699.5 & 435 \\
\hline Total Carbon $(\mathrm{mg} / \mathrm{L})$ & $\mathbf{7 8 5}$ & 515 \\
\hline
\end{tabular}

AA

\begin{tabular}{|l|c|c|}
\hline ADS\# & $\mathbf{3 0 0 1 4 0 3 9 5}$ & $\mathbf{3 0 0 1 4 0 3 9 6}$ \\
\hline $\mathrm{Na}(\mathrm{mg} / \mathrm{L})$ & 201.495 & 259.065 \\
\hline $\mathrm{K}(\mathrm{mg} / \mathrm{L})$ & $\mathbf{8 . 7 7 5}$ & 7.525 \\
\hline
\end{tabular}

Note: Identical samples were used for ADS \#300140393 through \#300140398. ICP-MS analysis indicated no masses other than 238 in the range 230-247 amu. 
8.4 Attachment 4. SuperLig 639 Resin Analysis Data

ICP-ES Data

\begin{tabular}{|c|c|c|c|c|c|}
\hline Sample & As-received & As-received & Tank 44 F Col. & Tank 44 F Col. & As-received* \\
\hline ADS \# & $\mathbf{3 0 0 1 3 7 3 7 5}$ & $\mathbf{3 0 0 1 3 7 3 7 4}$ & $\mathbf{3 0 0 1 3 7 3 7 3}$ & $\mathbf{3 0 0 1 3 7 3 7 2}$ & $\mathbf{3 0 0 1 3 1 5 0 0 - 3 0 0 1 3 1 5 0 3}$ \\
\hline & $\mathbf{w t .} \%$ & $\mathbf{w t}$ \% \% & wt. \% & wt. \% & wt. \% \\
\hline $\mathrm{Al}$ & {$[0.0961]$} & {$[0.1009]$} & {$[0.0286]$} & $<0.0522$ & 0.0036 \\
\hline $\mathrm{B}$ & $<0.0129$ & $<0.137$ & $<0.004$ & $<0.0109$ & 0.0107 \\
\hline $\mathrm{Ba}$ & {$[0.0053]$} & $<0.0055$ & $<0.0016$ & $<0.0043$ & $<0.0002$ \\
\hline $\mathrm{Ca}$ & 0.2396 & 0.248 & 0.0739 & 0.1947 & 0.0060 \\
\hline $\mathrm{Cd}$ & $<0.0077$ & $<0.0082$ & $<0.0031$ & $<0.0065$ & $<0.0002$ \\
\hline $\mathrm{Co}$ & {$[0.0138]$} & {$[0.0184]$} & {$[0.0042]$} & $<0.0109$ & $<0.0005$ \\
\hline $\mathrm{Cr}$ & $<0.018$ & $<0.0191$ & $<0.0056$ & $<0.0152$ & 0.0014 \\
\hline $\mathrm{Cu}$ & {$[0.0095]$} & {$[0.0088]$} & {$[0.0028]$} & $<0.0065$ & 0.0030 \\
\hline $\mathrm{Fe}$ & 0.0183 & 0.0213 & 0.0153 & 0.0481 & 0.0102 \\
\hline $\mathrm{La}$ & $<0.0283$ & $<0.0301$ & $<0.0087$ & $<0.0239$ & NA \\
\hline $\mathrm{Li}$ & $<0.0051$ & $<0.0055$ & $<0.0016$ & $<0.0043$ & $<0.0070$ \\
\hline $\mathrm{Mg}$ & 0.0140 & 0.0148 & 0.0037 & 0.0089 & $<0.0013$ \\
\hline $\mathrm{Mn}$ & $<0.0026$ & $<0.0027$ & $<0.0008$ & $<0.0022$ & $<0.0002$ \\
\hline $\mathrm{Mo}$ & $<0.0154$ & $<0.0164$ & $<0.0048$ & $<0.013$ & $<0.0004$ \\
\hline $\mathrm{Na}$ & 0.3017 & 0.3515 & 1.6927 & 1.8889 & $<0.0775$ \\
\hline $\mathrm{Ni}$ & {$[0.0291]$} & {$[0.028]$} & {$[0.0108]$} & $<0.0152$ & 0.0113 \\
\hline $\mathrm{P}$ & $<0.0669$ & $<0.071$ & $<0.0206$ & $<0.0565$ & $<0.0950$ \\
\hline $\mathrm{Pb}$ & {$[0.1031]$} & {$[0.1104]$} & {$[0.0225]$} & $<0.0609$ & $<0.0050$ \\
\hline $\mathrm{Si}$ & 0.1047 & {$[0.085]$} & {$[0.0254]$} & {$[0.0358]$} & $<0.0060$ \\
\hline $\mathrm{Sn}$ & $<0.0386$ & $<0.041$ & $<0.0119$ & $<0.0326$ & $<0.0040$ \\
\hline $\mathrm{Sr}$ & $<0.0026$ & $<0.0027$ & $<0.0008$ & $<0.0022$ & $<0.0005$ \\
\hline $\mathrm{Tc}$ & $<0.018$ & $<0.0191$ & $<0.0056$ & $<0.0153$ & NA \\
\hline $\mathrm{Ti}$ & {$[0.0081]$} & {$[0.0096]$} & {$[0.003]$} & $<0.0043$ & $<0.0149$ \\
\hline $\mathrm{V}$ & 0.0153 & {$[0.0163]$} & {$[0.0046]$} & $<0.0065$ & $<0.0012$ \\
\hline $\mathrm{Zn}$ & 0.0174 & 0.0204 & 0.0065 & 0.0113 & $<0.0011$ \\
\hline $\mathrm{Zr}$ & {$[0.0144]$} & {$[0.017]$} & {$[0.0054]$} & $<0.0087$ & $<0.0015$ \\
\hline & & & & & \\
\hline
\end{tabular}

Note: Dissolution of the resins was accomplished using a high-pressure, sealed vessel (Parr bomb) and concentrated nitric acid. $0.1 \mathrm{~g}$ of SuperLig ${ }^{\circledR} 639$ resin was added to the vessel with $3 \mathrm{ml}$ of concentrated $(16 \mathrm{M}) \mathrm{HNO}_{3}$. The temperature was raised to $150^{\circ} \mathrm{C}$ and maintained for 1.5 hours. Then the vessel was cooled and the sample was diluted with water to a final volume of $250 \mathrm{~mL}$ and analyzed by ICP-ES. Results in brackets were less than 2 times the minimum detection limit and are considered suspect.

*The "as-received" resin was reanalyzed at a dilution factor of 100:1. The average of four analyses, which were conducted on two original samples are reported. 